\title{
Emerging contaminants and priority substances in marine sediments from Cartagena Bay and the Grand Marsh of Santa Marta (Ramsar site), Colombia
}

\author{
Karina Caballero-Gallardo (D) J Jesus Olivero-Verbel • \\ Carmen Corada-Fernández · Pablo A. Lara-Martín · Ana Juan-García
}

Received: 15 January 2021 / Accepted: 10 August 2021 / Published online: 24 August 2021

(C) The Author(s), under exclusive licence to Springer Nature Switzerland AG 2021

\begin{abstract}
Emerging pollutants and priority substances are of growing concern due to their toxicity potential to aquatic organisms and human health. However, few reports on this issue in marine ecosystems in general and, more specifically, on the Colombian Caribbean coast are available. The aim of this study was to detect these compounds in sediments from Cartagena Bay (CB) and in the Grand Marsh of Santa Marta, GMSM (Ramsar site), in order to determine how they related to in vitro cytotoxicity assays on HepG2 cells
\end{abstract}

Supplementary Information The online version contains supplementary material available at https://doi. org/10.1007/s10661-021-09392-5.

K. Caballero-Gallardo $(\bowtie) \cdot$ J. Olivero-Verbel Environmental and Computational Chemistry Group. School of Pharmaceutical Sciences, Zaragocilla Campus, University of Cartagena, 130014 Cartagena, Colombia e-mail: kcaballerog@unicartagena.edu.co

\section{K. Caballero-Gallardo}

Functional Toxicology Group. School of Pharmaceutical Sciences, Zaragocilla Campus, University of Cartagena, 130014 Cartagena, Colombia

C. Corada-Fernández · P. A. Lara-Martín Campus of International Excellence of the Sea (CEI·MAR), Marine Research Institute (INMAR), University of Cadiz, 11510 Cadiz, Spain

A. Juan-García

Laboratory of Food Chemistry and Toxicology, Faculty of Pharmacy, University of Valencia, Av. Vicent Andrés Estellés s/n, 46100 BurjassotValència, Spain of sediment extracts. A total of thirty compounds were detected using GC-MS/MS in fifteen stations during both the rainy and the dry seasons. Sediments from CB had a wide range of different toxicants, with polycyclic aromatic hydrocarbons (PAHs) being the most prevalent (12 PAHs, 5.5-881.6 ng/g). Total PCBs ranged from < LOD to $18.6 \mathrm{ng} / \mathrm{g}$, with PCB 138 being the most common detected congener. Residues of $p, p^{\prime}$-DDE, Chlorpyrifos and two organophosphate flame retardants, TEHP and ToTP, were found in most sampling locations. The UV filters $4 \mathrm{MBC}$ and homosalate were recurrently found in sediments, and the fragrance galaxolide appeared in all cases, with the greatest concentrations found on a touristic beach. In GMSM, with the exception of deltamethrin, all chemicals evaluated had lower average values than in CB. According to sediment quality guidelines, some sites in $\mathrm{CB}$ presented values of PAHs higher than the threshold effects level, while in the marsh, none of the stations exceeded it. HepG2 cells exposed to $1 \%$ sediment extracts presented reduced cell viability up to $26 \%$. Cytotoxicity displayed a negative correlation with chlorpyrifos concentration. In short, these data suggest the bay and the marsh have specific contamination fingerprints related to anthropogenic interventions. This research highlights the need to further investigate the ecotoxicological implications of detected chemical stressors in these ecosystems.

Keywords Pollutants · UV filters · Fragrances · Pesticides · PAHs · HepG2 - Coastal ecosystems 


\section{Introduction}

Marine environments are one of the most fragile ecosystems in earth and are considered major receptors of wastewater discharges since populated areas and economical activities (e.g., shipping) are concentrated on the coast. Once in the water, pollutants reach the sediments, considered the main sink of anthropogenic chemicals in aquatic ecosystems, including contaminants of emerging concern (CECs), such us UV filters (UVF) (He et al., 2019), and fragrances (Subedi et al., 2014), as well as priority substances, among them, organophosphorus flame retardants (OPFRs) (Cristale et al., 2013), polycyclic aromatic hydrocarbons (PAHs) (Caballero-Gallardo et al., 2015), pesticides (DuarteRestrepo et al., 2021), and polychlorinated biphenyls (PCBs) (Morales-Caselles et al., 2017). A fraction of these chemical compounds is continuously reintroduced into the water column from sediments through resuspension and trophic transfer, which facilitates their bioaccumulation and the generation of adverse effects in biota (Pico et al., 2019). One particular aspect of many emerging and priority pollutants is that their high rates of production allow them to be continuously incorporated into the environment.

At the Colombian Caribbean, Cartagena Bay (CB) is a key marine ecosystem since colonial times, as it represents a commercial gateway to America due to its strategic location and natural conditions. Today, cargo and touristic ports, together with petrochemical, chemical, food, pesticides, and maritime industries, occupy the eastern part of the bay. The estuary also receives massive sediments and pollutants from the Colombian Andes through the Dique Channel, a manmade connection with Magdalena River; this last considered one with the highest sediment discharges in the world (Mouyen et al., 2018). Environmental pollution in the Bay made it necessary to prohibit artisanal fishing there. However, many communities still derive their livelihood from the biological resources obtained from this body of water.

Previous studies in CB sediments have documented the presence of a number of pollutants, including aromatic hydrocarbons (Parga-Lozano et al., 2002), pesticides (Duarte-Restrepo et al., 2021; JaramilloColorado et al., 2015), metals (Caballero-Gallardo et al., 2020), and PCBs (Duarte-Restrepo et al., 2021). However, the information on many CECs and priority pollutants is still scarce. Even more important, there is a lack of data regarding the biological effects of the sediment-bound toxicants, a critical point for assessing ecological risk assessment (Tarnawski \& Baran, 2018). An important tool for determining the possible effects of these pollutants is the use of in vitro cell culture models. For instance, bioassays employing human hepatocarcinoma HepG2 cells have been convenient to estimate environmental and human health risk of sediment-bound chemical mixtures (Pinto et al., 2014), as these cells respond to high frequently found stressors in sediments, such as pesticides (Dehn et al., 2005; Medina-Díaz \& Elizondo, 2005), PAHs (Ma et al., 2019), and PCBs (Wei et al., 2012).

The goals of this study were to (1) quantify the levels of several CECs, such as UVFs, fragrances, and OPFRs, as well as several priority substances (pesticides, PAHs, and PCBs) in sediments from Cartagena Bay, comparing its pollution profile with that of the Grand Marsh of Santa Marta (GMSM), a site without history of industrial pollution; (2) measure the cytotoxicity of sediment extracts from both sampling sites using the HepG2 cell model; and (3) identify its association with the concentration of pollutants in both sites.

\section{Materials and methods}

Study areas

The study was performed by collecting samples from two strategic points located in the Colombian Caribbean coast: Cartagena Bay (CB), whose main source of contamination is the industrial zone of Mamonal, sediments from the Dique Channel and its beaches (tourist attraction in the city) and the Grand Marsh of Santa Marta (GMSM), a body of water with no industries, but subjected to severe pressures from industrial crops.

Cartagena Bay $\left(10^{\circ} 21^{\prime} 54^{\prime \prime} \mathrm{N}\right.$ and $\left.75^{\circ} 31^{\prime} 48^{\prime \prime} \mathrm{W}\right)$ (Fig. 1) is an estuary of industrial importance on the Caribbean coast, and it has one of the best coral reefs on the continental shelf of Colombia (LópezVictoria et al., 2015). This estuary is surrounded on its east side by the city of Cartagena, and a great portion of its coastline lies in the Mamonal industrial area. In the Bay, there are several ports and 


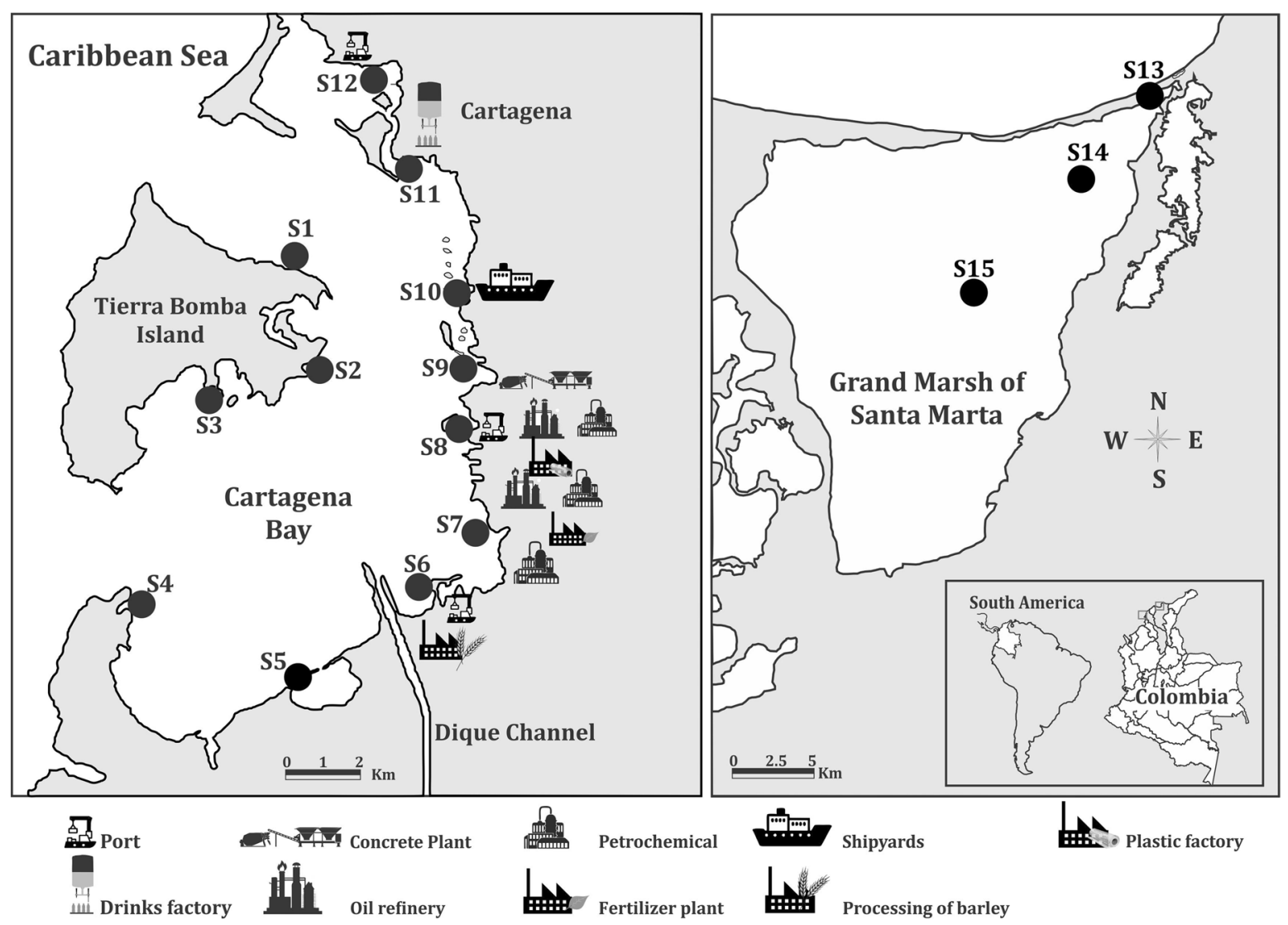

Fig. 1 Geographic location of sampling stations

shipping operations, as well as over 70 industries (Cardique, 2006), some with water treatment plants that discharge directly or indirectly in it. Major industries found in CB include oil refineries, cement production plants, ship repair, and food and beverage factories, among others. In addition, the CB receives several sources of wastewater from Cartagena, a historical and tourist city that surrounds it which has approximately 1 million inhabitants. This city is the second most visited destination in Colombia by foreigners from the USA mainly. However, by 2020 , tourism was affected by $69.5 \%$ compared to 2019 (Mincomercio, 2021) as a consequence of the COVID-19 pandemic. Several years ago, almost $50 \%$ of the domestic wastewater from the city was being disposed in the Bay (Heredia et al., 2013). This aquatic ecosystem also receives freshwater and sediments from the Dique Channel, thus acquiring special conditions of productive wealth for fishing and aquaculture purposes. In the city of Cartagena, the rainy season (RS) goes from April to November, sometimes even extending until the second week of December, experiencing the highest rates of rainfall in October. The dry season (DS) occurs from December to March (CIOH, 2021a).

On the other hand, the Grand Marsh of Santa Marta (GMSM) is located in northwestern Colombia in the Department of Magdalena $\left(10^{\circ} 45^{\prime} \mathrm{N}\right.$ and $\left.74^{\circ} 29^{\prime} \mathrm{W}\right)$. Many communities depend on this site for fishing, and its ecological importance has been recognized by the declaration of two National Natural Parks in its interior with designation no. 951 (18-06-1998) designating it as a Ramsar site, and as a biosphere reserve by UNESCO in 2000 (RAMSAR, 1998; UNESCO, 2000). The GMSM has an average water temperature of $29{ }^{\circ} \mathrm{C}$. The dry season runs from December to April, a transition period begins until July, and the rainy season occurs from August until November (CIOH, 2021b). In contrast 
to $\mathrm{CB}$, the GMSM receives pollution mostly from agriculture (banana and African palm crops), and livestock.

\section{Marine sediment collection}

A total of 12 marine surface sediment samples from $\mathrm{CB}$ (S1-S12) and 3 from the GMSM (S13-S15) were collected with an Eckman dredger in September 2017 (Rainy season, RS) and February 2018 (Dry season, DS). A composite sample was collected at each sampling station and stored at $-20{ }^{\circ} \mathrm{C}$, freeze-dried, and homogenized using a 200 mesh sieve ( $<75 \mathrm{um})$ (Caballero-Gallardo et al., 2015, 2020; Olivero-Verbel et al., 2015). The geographic location of the sampling stations, as well as possible sources of pollution, is shown in the Supplementary Information (Table S1).

\section{Analysis of emerging and priority compounds}

Chemical analysis on sediment samples of 86 compounds was analyzed (Table S2); selected target compounds are listed in Table S3. Extraction of target compounds from sediment samples was achieved through pressurized liquid extraction (PLE) using an accelerated solvent extractor ASE 200 from Dionex (Sunnyvale, CA, USA) equipped with 11-mL stainlesssteel cells. Purification of the extracts was performed simultaneously with the extraction (in-cell cleanup) by placing sorbents inside the cell (activated alumina) (Pintado-Herrera et al., 2016). Separation, identification, and quantification of target contaminants were performed using gas chromatography (SCION 456-GC, Bruker) coupled to triple quadrupole mass spectrometry (SCION TQ from Bruker with CP 8400 Autosampler) (Pintado-Herrera et al., 2016). Analyses were conducted in the laboratory of the Marine Research Institute of the University of Cadiz. The full description of the reagents, analytical procedures applied, and the specific recoveries for each chemical are included in the Supplementary material section (SM).

\section{Quality assurance GC-MS/MS method}

The analytical method used showed coefficients of determination $\left(R^{2}\right)$ higher than 0.95 for the calibration curves of all analytes. The limits of detection (LOD) and quantitation (LOQ) were estimated based on a signal to noise $(\mathrm{S} / \mathrm{N})$ ratio of 3 to 10 , respectively.
The LOD ranged from 0.010 to $1.338 \mathrm{ng} / \mathrm{g}$ (Table S3, Supporting Information) in terms of accuracy and precision. The method was based on work previously described by Pintado-Herrera et al. (2016). The behavior of all analytes was linear within the aforementioned range, showing determination coefficients $\left(R^{2}\right)$ higher than 0.95 . The LOD and LOQ were estimated based on a signal-to-noise $(\mathrm{S} / \mathrm{N})$ ratio of 3 to 10 , respectively. The LOD ranged from 0.010 to $1.338 \mathrm{ng} / \mathrm{g}$ (Table S3, Supporting Information). The recovery test (Table S4) showed satisfactory results, with extraction efficiencies between 55 and $100 \%$ that were comparable to the previous literature (Barco-Bonilla et al., 2009). The precision of the methodology was studied assessing the relative standard deviations (\%RSD). The RSDs were always below $15 \%$, indicating that the employed methodology was precise.

\section{Sediment quality guidelines}

The environmental risk on benthic organisms, linked to the levels of PAHs in sediments, can be estimated based on sediment quality guideline (SQGs). Although there is a number of these indices, frequently used ones include the threshold effect level (TEL), effect range low (ERL), probable effect level (PEL), and the effect range median (ERM) (Akhbarizadeh et al., 2016; McGrath et al., 2019). It has been suggested that when sediment levels are lower than the TEL and ERL, adverse effects on organisms would rarely be detected. However, when those are greater than PEL or ERM, adverse effects are more likely to occur (Manuel Nicolaus et al., 2015).

\section{Diagnostic ratios for PAHs}

The sources of PAHs in the samples examined were assessed by calculating the PAH diagnostic ratio $\mathrm{Fl} /$ Pyr. The criterion employed in the interpretation of the value as an indicator of the PAH source was as follows: values $<1$ and $>1$ correspond to sources petrogenic and pyrolytic, respectively (Baumard et al., 1998a; Sicre et al., 1987).

\section{Cytotoxicity assays}

Ten grams of dry sediment samples $(<75 \mu \mathrm{m})$ were mixed with $30 \mathrm{~mL}$ of methanol (Merck) and placed in a Shaker MAXQ 4450 at conditions of 
$30{ }^{\circ} \mathrm{C}$ and $300 \mathrm{rpm}$, for $24 \mathrm{~h}$. The supernatant was removed, centrifuged at $3000 \mathrm{~g}$ for $10 \mathrm{~min}$ and filtered through a $0.22-\mu \mathrm{m}$ pore membrane filter. Subsequently, the supernatant was concentrated in a rotary evaporator, freeze dried, dissolved in dimethyl sulfoxide (DMSO), and kept at $4{ }^{\circ} \mathrm{C}$ until cytotoxicity tests were performed.

HepG2 cells (ATCC HB-8065) were grown using protocols previously reported in the literature (JuanGarcía et al., 2019a, 2019b). The passage number range was maintained between 2 and 6 . The cells were seeded into 96 -well plates $\left(2 \times 10^{4}\right.$ cells/well $)$ and incubated at $5 \% \mathrm{CO}_{2}, 37{ }^{\circ} \mathrm{C}$ for $24 \mathrm{~h}$. Dilution of methanolic extracts were prepared in a medium (1\% DMSO), obtaining concentrations from 0 to $1 \%$ of the extract. Cell viability was determined using the MTT assay ( $5 \mathrm{mg} / \mathrm{mL}$ MTT in PBS) following methodologies reported by Juan-García et al. (2019b).

\section{Statistical analysis}

Data are expressed as mean \pm standard errors. Normality and homoscedasticity were checked using Shapiro-Wilk and Bartlett's tests, respectively. Mean values between seasons were compared using the Student's $t$-test. Wilcoxon test was used for variables without normal distribution. Correlation coefficients were obtained using Spearman's correlation. The multivariate relationships between the concentrations of each emerging contaminant, sampling sites, and weather seasons were examined using a principal component analysis in order to find relationships between different compounds found in sediments and their similarities. Data analysis was conducted on GraphPad Prism 6.0 (GraphPad Prisma Software, Inc., San Diego, USA) and IBM SPSS Statistics (version 21, IBM SPSS Inc., Chicago, IL). Statistical significance was set at $p<0.05$.

\section{Results}

PAHs

The levels of PAHs in sediments and their corresponding SQG values are shown in Table 1. In CB, the $\sum$ PAH concentrations in sediments ranged from 16.6 (S1) to $881.6 \mathrm{ng} / \mathrm{g}$ (S10) during the rainy season (RS); whereas, during the dry season (DS), the levels oscillated between 5.46 (S1) and $345.9 \mathrm{ng} / \mathrm{g}$ (S11). The overall mean concentration for total PAHs was $186.9 \pm 41.7 \mathrm{ng} / \mathrm{g}$. The stations that presented concentrations of total PAHs $>300 \mathrm{ng} / \mathrm{g}$ were S7 (571.63 ng/g), S10 (881.6 ng/g), S11 (327.9 ng/g), and S12 (365.3 ng/g). Although PAH concentrations showed different levels of pollution between sampling sites, $\sum$ PAH content was not statistically different ( $p=0.622$ ) between seasons according to Wilcoxon matched-pairs signed-rank test. Sampling sites S9 (DS), S10 (RS and DS), S11 (RS), and S12 (RS) were the stations with the greater number of PAHs.

The ratio $\mathrm{Fl} / \mathrm{Pyr}$ was employed as a molecular index to identify potential PAH sources. Diagnostic ratios $\mathrm{Fl} / \mathrm{Pyr}$ obtained from $\mathrm{PAH}$ concentrations are displayed in Fig. 2. In CB, the sources of PAH varied according to season: during the rainy season, $66.7 \%$ of the sites showed the main sources of PAHs were petrogenic, followed by pyrogenic (33.3\%). The profile was different during the dry season, with 75 and $25 \%$ of the sampling sites corresponding to pyrogenic and petrogenic sources, respectively. The results for S7 showed sediment PAHs were petrogenic in nature for both sampling campaigns.

In the case of GMSM, the concentrations of PAHs ranged from 22.7 (S13) to $41.9 \mathrm{ng} / \mathrm{g}$ (S15) during the rainy season, and from $38.9 \mathrm{ng} / \mathrm{g}$ (S13) to $62.5 \mathrm{ng} / \mathrm{g}$ (S15) during the dry season, with an overall mean concentration of $43.06 \pm 6.25 \mathrm{ng} / \mathrm{g}$. As was also observed in $\mathrm{CB}$, total PAH content was not statistically different between seasons (Wilcoxon test, $p=0.250$ ). The largest number of PAHs found in sediments from the Marsh was 9 for S13 (DS), S14 (DS), and S15 (RS and DS). The station with the highest total PAHs concentrations was S15. Fl/ Pyr ratio showed that $100 \%$ of the PAHs in the stations studied were from pyrogenic during the dry season.

PAH concentrations were then compared to several SQGs. None of the marine sediment PAH concentrations surpassed the ERM value. However, in the $\mathrm{CB}$, the $\mathrm{S} 7$ (BaPyr, RS), S10 (Acy, Phe, and Fl, RS and DS), S11 (Acy, RS), and S12 (Acy, RS) stations displayed PAH concentrations greater than the TEL, while in GMSM, none of the stations exceeded these guidelines. 


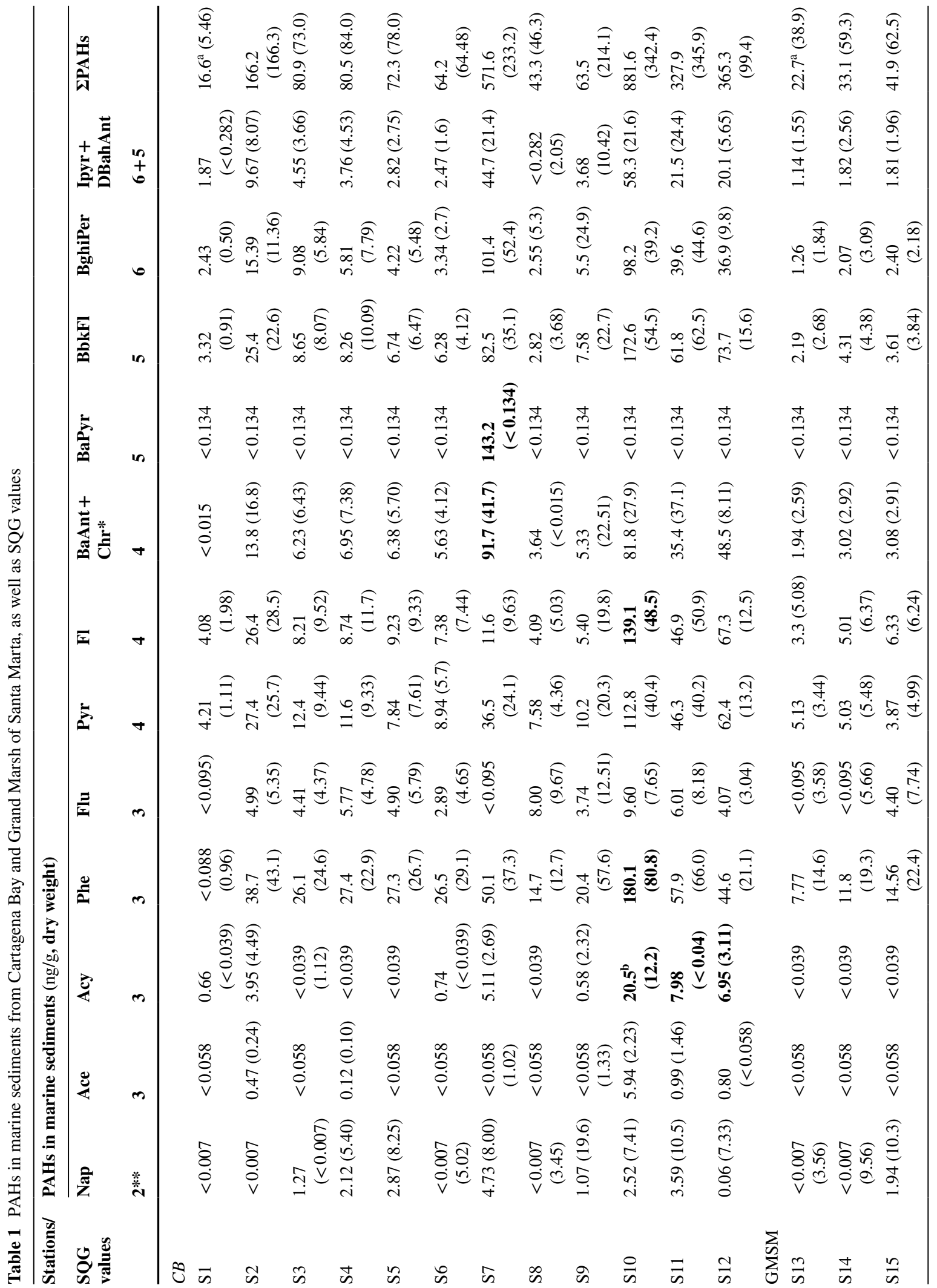




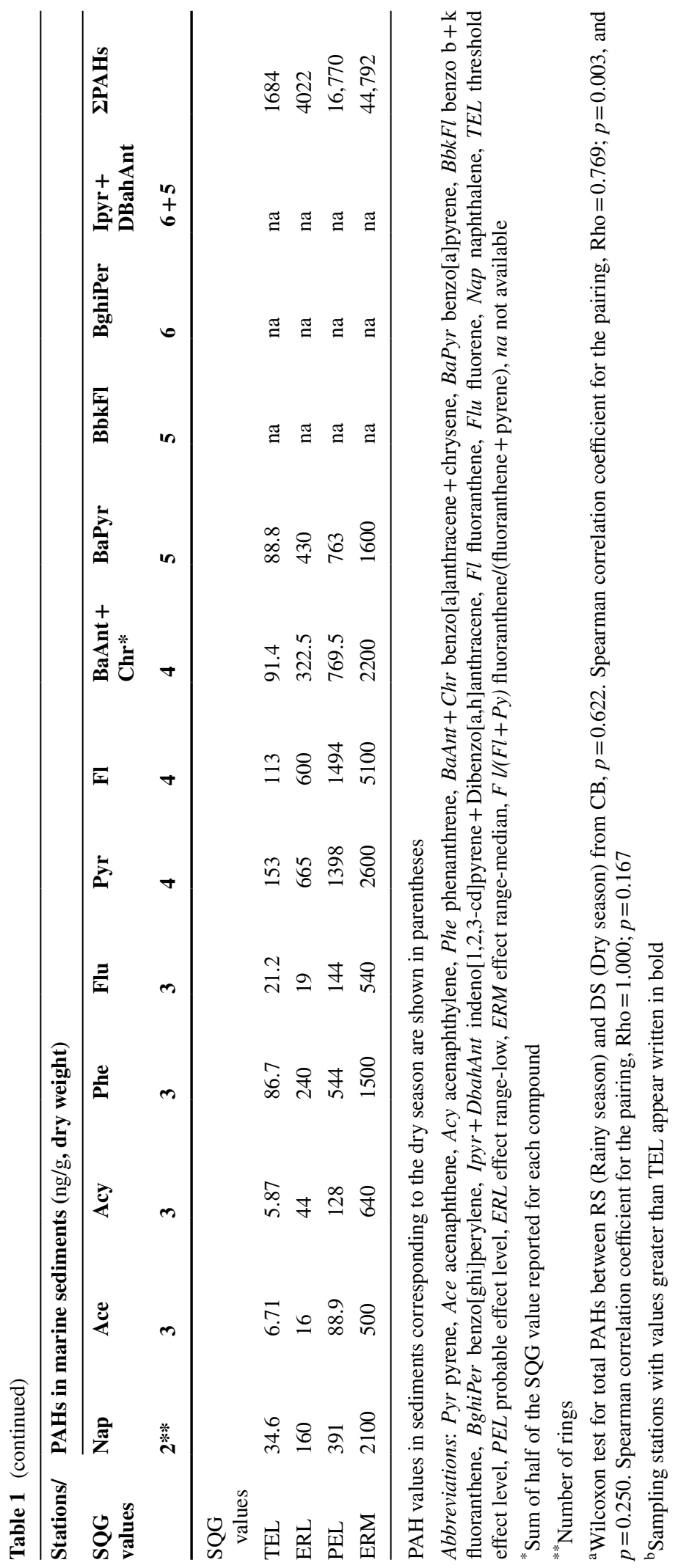


Fig. 2 Potential sources of PAHs in marine sediments from Cartagena Bay (S1-S12) and Grand Marsh of Santa Marta (GMSM, S13-S15)
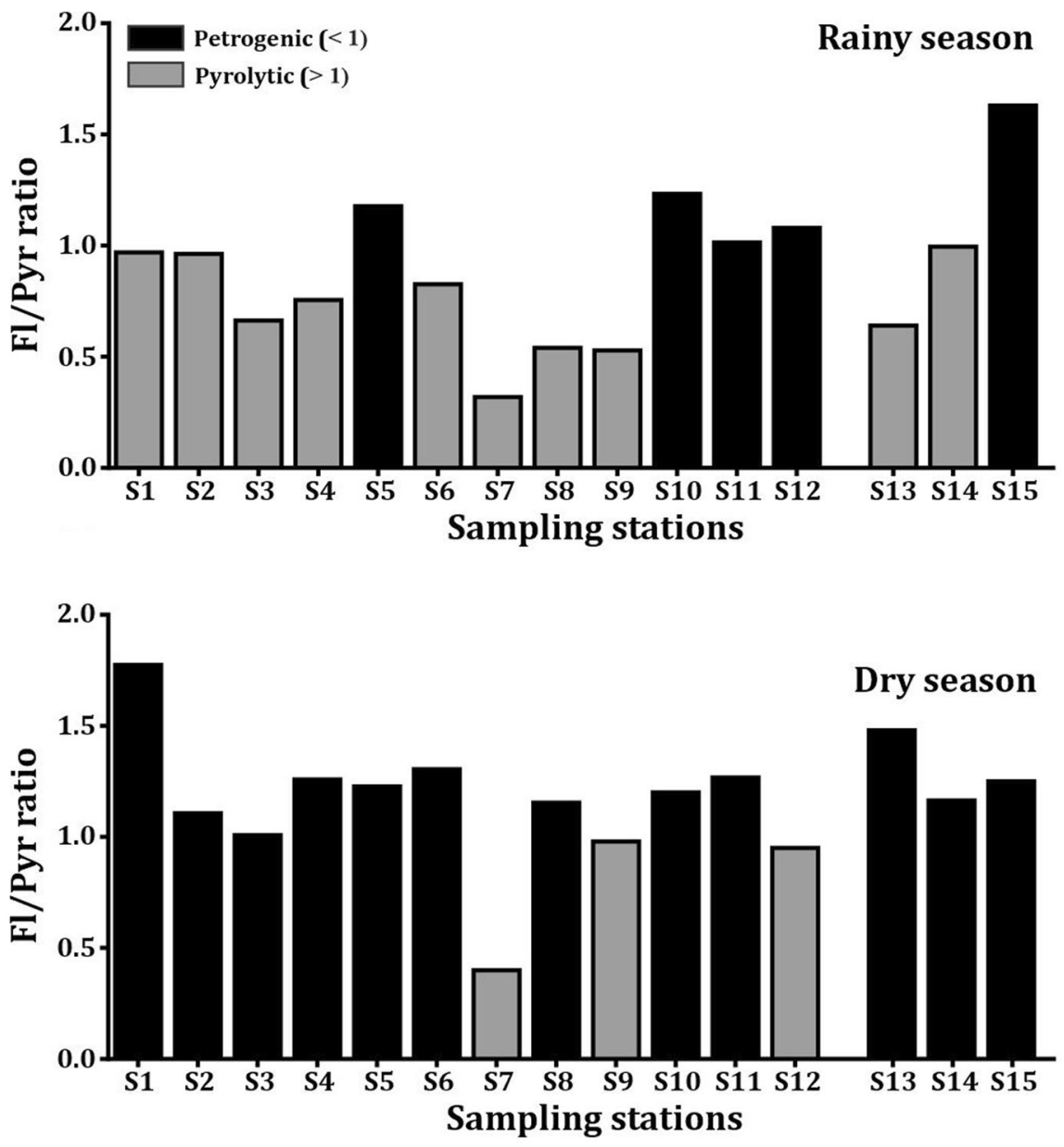

PCBs

PCBs were found in ten out of thirteen stations analyzed in CB (Table 2). Total PCBs measured at the 12 stations in $\mathrm{CB}$ ranged from $<$ LOD (RS and DS) to $15.2 \mathrm{ng} / \mathrm{g}$ in the rainy season and $18.59 \mathrm{ng} / \mathrm{g}$ in the dry season. The PCB concentrations were generally elevated at the S2, S7, S8, S10, S11, and S12 stations. PCB 138 was the most common detected congener in sediments in most stations, with levels ranging from 0.11 to $6.72 \mathrm{ng} / \mathrm{g}$. It is important to highlight that PCBs were not detected in the GMSM.

Pesticides

The levels of pesticides observed in sediments are shown in Table 3. Residues of $p, p^{\prime}$-DDE were found in 10 stations from $\mathrm{CB}$, with the exception of stations $\mathrm{S} 1$ and S8. The highest contents of $p, p^{\prime}$-DDD and $p, p^{\prime}$-DDE were detected at station $\mathrm{S} 12(0.30 \mathrm{ng} / \mathrm{g}, \mathrm{RS} ; 0.61 \mathrm{ng} / \mathrm{g}, \mathrm{DS})$ and $\mathrm{S} 11$ $(0.18 \mathrm{ng} / \mathrm{g}, \mathrm{RS} ; 0.52 \mathrm{ng} / \mathrm{g}, \mathrm{DS})$. In addition, the highest DDD/DDE ratios were found in S4, S5, S6, and S10. Chlorpyrifos was found in all sampling stations with exception of S1. In GMSM, $p, p^{\prime}$-DDE levels were not detected; however, high concentrations of deltamethrin and chlorpyrifos were detected. The greatest concentrations of deltamethrin were observed at S14 $(6.50 \mathrm{ng} / \mathrm{g}$, RS and $48.9 \mathrm{ng} / \mathrm{g}, \mathrm{DS})$ and S15 (14.6 ng/g, RS and $17.2 \mathrm{ng} / \mathrm{g}, \mathrm{DS})$.

Organophosphate flame retardants in sediments

The concentrations of OPFRs found at $\mathrm{CB}$ and GMSM are summarized in Table 4. Among the 3 OPFRs tested for, two compounds had a detection rate over $60 \%$ for all sediment samples from 
Table 2 Concentration of PCBs in sediment samples from CB (stations S1 to S12) and GMSM (stations 13 to S15) (ng/g, dw) during the rainy and dry seasons

\begin{tabular}{|c|c|c|c|c|c|c|}
\hline Stations & PCB52 & PCB101 & PCB138 & PCB153 & PCB180 & $\Sigma \mathrm{PCBs}$ \\
\hline \multicolumn{7}{|l|}{$C B$} \\
\hline $\mathrm{S} 1$ & $<0.009$ & $<0.009$ & $<0.003$ & $<0.020$ & $<0.005$ & $<$ LOD \\
\hline $\mathrm{S} 2$ & $<0.009$ & $0.12(<0.009)$ & $0.25(0.10)$ & $<0.020$ & $0.22(<0.005)$ & $0.59(0.10)$ \\
\hline S3 & $<0.009$ & $<0.009$ & $0.14(0.11)$ & $<0.020$ & $<0.005$ & $0.14(0.11)$ \\
\hline S4 & $<0.009$ & $<0.009$ & $0.11(0.16)$ & $<0.020$ & $<0.005$ & $0.11(0.16)$ \\
\hline S5 & $<0.009$ & $<0.009$ & $0.11(0.11)$ & $<0.020$ & $<0.005$ & $0.11(0.11)$ \\
\hline S6 & $<0.009$ & $<0.009$ & $<0.003$ & $<0.020$ & $<0.005$ & $<\mathrm{LOD}$ \\
\hline S7 & $<0.009$ & $0.18(<0.009)$ & $0.81(0.36)$ & $0.90(0.61)$ & $0.91(0.49)$ & $2.81(1.46)$ \\
\hline S8 & $<0.009$ & $0.17(<0.009)$ & $0.66(0.38)$ & $<0.020(0.61)$ & $0.73(0.41)$ & $1.55(1.40)$ \\
\hline S9 & $<0.009$ & $<0.009$ & $0.15(0.26)$ & $<0.020$ & $<0.005(0.25)$ & $0.15(0.51)$ \\
\hline $\mathrm{S} 10$ & $<0.009$ & $0.28(0.19)$ & $0.77(0.64)$ & $0.66(<0.020)$ & $0.42(0.41)$ & $2.13(1.24)$ \\
\hline $\mathrm{S} 11$ & $0.39(0.65)$ & $1.21(1.50)$ & $5.42(6.72)$ & 4.29 (4.59) & $3.90(5.13)$ & $15.22(18.59)$ \\
\hline $\mathrm{S} 12$ & $0.10(0.10)$ & $0.21(0.20)$ & $1.01(0.52)$ & $0.83(<0.020)$ & $0.56(0.35)$ & $2.70(1.16)$ \\
\hline \multicolumn{7}{|l|}{ GMSM } \\
\hline $\mathrm{S} 13$ & $<0.009$ & $<0.009$ & $<0.003$ & $<0.020$ & $<0.005$ & $<$ LOD \\
\hline S14 & $<0.009$ & $<0.009$ & $<0.003$ & $<0.020$ & $<0.005$ & $<$ LOD \\
\hline $\mathrm{S} 15$ & $<0.009$ & $<0.009$ & $<0.003$ & $<0.020$ & $<0.005$ & $<$ LOD \\
\hline
\end{tabular}

PCB values in sediments corresponding to the dry season are shown in parentheses

CB, TEHP (92\%), and ToTP (67\%). In contrast, 2-ethylhexyl diphenyl phosphate had a detection rate of only $17 \%$. The concentrations of individuals OPFRs varied in sediments from different sampling sites. The $\Sigma$ OPFR levels for all sampling stations in $\mathrm{CB}$ ranged from $<\mathrm{LOD}$ to $11.90 \mathrm{ng} / \mathrm{g}$ and from < LOD to $1.00 \mathrm{ng} / \mathrm{g}$ for the RS and DS, respectively. The mean concentrations of OPFRs decreased in the following order TEHP (RS: $1.71 \pm 0.90 \mathrm{ng} / \mathrm{g}$ and DS: $1.67 \pm 0.90 \mathrm{ng} / \mathrm{g})>$ ToTP $(\mathrm{RS}: 0.53 \pm 0.12 \mathrm{ng} / \mathrm{g}$ and DS: $0.77 \pm 0.03 \mathrm{ng} / \mathrm{g})>2$-ethylhexyl diphenyl phosphate (RS: $0.10 \pm 0.03 \mathrm{ng} / \mathrm{g}$ and DS: $0.09 \pm 0.03 \mathrm{ng} / \mathrm{g}$ ). The highest TEHP concentrations were found in sediments collected from S7 (RS: $11.17 \mathrm{ng} / \mathrm{g}$ and DS: $11.10 \mathrm{ng} / \mathrm{g}$ ), S10 (RS: $2.87 \mathrm{ng} / \mathrm{g}$ and DS: $2.16 \mathrm{ng} / \mathrm{g}$ ), S11 (RS: $2.29 \mathrm{ng} / \mathrm{g}$ and DS: $1.96 \mathrm{ng} / \mathrm{g}$ ), and S12 (RS: $1.79 \mathrm{ng} / \mathrm{g}$ and DS: $0.96 \mathrm{ng} / \mathrm{g}$ ).

In the GMSM, only ToTP was detected, and it appeared in both sampling seasons (RS: $0.73 \pm 0.02 \mathrm{ng} / \mathrm{g}$ and DS: $0.25 \pm 0.24 \mathrm{ng} / \mathrm{g}$ ). The $\Sigma$ OPFR concentrations for all sampling stations ranged from 0.69 to $0.75 \mathrm{ng} / \mathrm{g}$ and from $<\mathrm{LOD}$ to $0.72 \mathrm{ng} / \mathrm{g}$ for RS and DS, respectively.

\section{UV filters and fragrances}

The concentrations of UV filters and fragrances in marine sediments from CB and GMSM are shown in Table 5. In Cartagena Bay, a high occurrence of $4 \mathrm{MBC}$ was found in $\mathrm{S} 7$ in both sampling seasons $(52.8 \mathrm{ng} / \mathrm{g}, \mathrm{RS}$ season and $18.0 \mathrm{ng} / \mathrm{g}$, DS). Other stations that presented residues of this UV filter were S10 (3.55 ng/g, RS), S11 (1.11 ng/g, RS and $0.68 \mathrm{ng} / \mathrm{g}$, DS), and S12 (0.32 ng/g, RS). However, homosalate was found only during the DS in S1 (19.3 ng/g), S2 (14.36 ng/g), S9 (15.88 ng/g), and S10 (16.04 ng/g). In the case of fragrances, galaxolide showed $100 \%$ frequency, with the highest concentrations being found at stations S1 (11.6 ng/g, RS and $11.2 \mathrm{ng} / \mathrm{g}, \mathrm{DS}$ ) and S2 (RS: $19.1 \mathrm{ng} / \mathrm{g}$ and DS: $10.8 \mathrm{ng} / \mathrm{g}$ ).

In the GMSM, 4MBC and tonalide were not detected, whereas homosalate was found at S14 (RS: $15.06 \mathrm{ng} / \mathrm{g}$ ), and S15 (RS: $14.67 \mathrm{ng} / \mathrm{g}$ and DS: $14.37 \mathrm{ng} / \mathrm{g}$ ). In addition, galaxolide was found in all sampling stations. 
Table 3 Concentration of pesticides in sediment samples from CB and GMSM (ng/g, dw) during the rainy and dry seasons

\begin{tabular}{|c|c|c|c|c|c|}
\hline Stations/SQG values & $p, p^{\prime}-\mathrm{DDD}$ & $p, p^{\prime}-\mathrm{DDE}$ & DDD/DDE ratio & Deltamethrin(alfa + beta) & Chlorpyrifos \\
\hline \multicolumn{6}{|l|}{$C B$} \\
\hline S1 & $<0.028$ & $<0.012$ & $-(-)$ & $<0.401$ & $<0.145$ \\
\hline $\mathrm{S} 2$ & $0.12(0.11)$ & $0.20(0.084)$ & $0.6(1.4)$ & $1.87(<0.401)$ & $1.33(5.95)$ \\
\hline S3 & $0.11(0.10)$ & $0.12(0.070)$ & $0.9(1.4)$ & $<0.401$ & $0.64(1.13)$ \\
\hline S4 & $0.12(0.12)$ & $0.11(0.10)$ & $1.1(1.2)$ & $10.26(4.48)$ & $0.86(0.98)$ \\
\hline S5 & $0.15(0.13)$ & $0.072(0.050)$ & $2.1(2.6)$ & $<0.401$ & $1.16(3.06)$ \\
\hline S6 & $0.13(0.13)$ & $0.069(0.061)$ & $1.9(2.2)$ & $<0.401$ & $0.68(0.46)$ \\
\hline S7 & $<0.028$ & $0.38(0.24)$ & $-(-)$ & $<0.401$ & $0.99(0.47)$ \\
\hline S8 & $<0.028(0.092)$ & $<0.012$ & $-(-)$ & $<0.401$ & $0.42(0.50)$ \\
\hline S9 & $<0.028(0.17)$ & $<0.012(0.17)$ & $-(1.0)$ & $<0.401$ & $0.59(1.12)$ \\
\hline $\mathrm{S} 10$ & $0.13(0.11)$ & $0.11(0.11)$ & $1.2(1.0)$ & $<0.401(4.27)$ & $0.45(1.94)$ \\
\hline S11 & $0.18(0.15)$ & $0.52(0.41)$ & $0.3(0.4)$ & $<0.401(4.95)$ & $0.68(0.75)$ \\
\hline $\mathrm{S} 12$ & $0.30(0.12)$ & $0.61(0.28)$ & $0.5(0.4)$ & $<0.401$ & $1.07(0.50)$ \\
\hline \multicolumn{6}{|l|}{ GMSM } \\
\hline S13 & $0.10(<0.028)$ & $<0.012$ & $-(-)$ & $0.92(<0.401)$ & $<0.145$ \\
\hline S14 & $<0.028(0.093)$ & $<0.012$ & $-(-)$ & $6.50(48.90)$ & $0.56(0.98)$ \\
\hline $\mathrm{S} 15$ & $<0.028(0.087)$ & $<0.012$ & $-(-)$ & $14.57(17.18)$ & $0.29(0.69)$ \\
\hline \multicolumn{6}{|l|}{$S Q G$ values } \\
\hline TEL & 1.22 & 2.07 & & na & na \\
\hline PEL & 7.81 & 374 & & na & na \\
\hline ERL & 2 & 2.2 & & na & na \\
\hline ERM & 20 & 27 & & na & na \\
\hline
\end{tabular}

Pesticide values in sediments corresponding to the dry season are shown in parentheses

Cytotoxicity of HepG2 exposed to methanolic sediment extracts from CB and GMSM

The results of viability of HepG2 cells exposed to the methanolic sediment extracts are presented in Fig. 3 and Table S5. After $24 \mathrm{~h}$ of exposure, sediment extracts from seven stations: S2(RS), S3(RS), S4(RS), S15(RS), S2(DS), S6(DS), and S9(DS) induced significant changes on HepG2 cell viability below $50 \%$. A moderate negative correlation was found between cytotoxic activity and chlorpyrifos concentration in sediments $(\rho=-0.451 ; p=0.012)$ (Table S6 and Fig. S1).

\section{Discussion}

Sediments accumulate several types of contaminants present in the water or suspended particles, and its importance on aquatic ecosystem quality and wildlife is well known. However, studies on the quality of sediments in Colombian coastal areas are scarce, and particularly so for the Cartagena Bay, an ecosystem which is not only surrounded by industries and urban areas, but is also a home for mangroves and coral reefs. Pollutants enter the bay from runoff, industrial facilities, domestic wastewater discharges, and atmospheric deposition, among other sources. These pollutants, which are present in sediments, can accumulate in local biota (Alonso et al., 2000; Olivero-Verbel et al., 2009). Due to the above, in the present study, the authors have tried to describe different sources of pollution and to elucidate the potential toxicity of these sediments with in vitro tests. In addition, this is the first study that reports some of contaminants of emerging concern, as well as priority substances in sediments of two ecosystems of great importance in the Caribbean region of Colombia.

PAHs are pollutants that are often found in coastal marine environments impacted by industry and shipping traffic. These compounds are derived from the combustion of organic material or from 
Table 4 Concentration of organophosphate flame retardants (OPFRs) in sediment samples from CB and GMSM (ng/g, dw) during the rainy and dry seasons

\begin{tabular}{lllll}
\hline Stations & TEHP & ToTP & EHDPP & IOPFRs \\
\hline CB & & & \\
S1 & $<0.005$ & $<0.019(0.71)$ & $<0.091$ & $<$ LOD $(0.71)$ \\
S2 & $0.32(0.13)$ & $0.68(0.64)$ & $<0.091$ & $1.00(0.64)$ \\
S3 & $0.26(0.24)$ & $<0.019(0.69)$ & $<0.091$ & $0.26(0.69)$ \\
S4 & $0.31(0.20)$ & $0.70(0.71)$ & $<0.09(0.21)$ & $1.01(0.71)$ \\
S5 & $0.11(0.076)$ & $0.71(0.72)$ & $<0.091$ & $0.82(0.72)$ \\
S6 & $0.35(0.26)$ & $0.68(0.75)$ & $0.25(<0.091)$ & $1.28(0.75)$ \\
S7 & $11.17(11.10)$ & $0.73(0.67)$ & $<0.091$ & $11.90(0.67)$ \\
S8 & $0.65(0.32)$ & $0.84(0.70)$ & $0.29(<0.091)$ & $1.78(0.70)$ \\
S9 & $0.34(2.58)$ & $1.12(0.88)$ & $0.27(0.37)$ & $1.73(0.88)$ \\
S10 & $2.87(2.16)$ & $<0.019(0.96)$ & $<0.091$ & $2.87(0.96)$ \\
S11 & $2.29(1.96)$ & $0.89(1.00)$ & $<0.091$ & $3.18(1.00)$ \\
S12 & $1.79(0.96)$ & $<0.019(0.75)$ & $<0.091$ & $1.79(0.75)$ \\
GMSM & & & & \\
S13 & $<0.005$ & $0.75(<0.019)$ & $<0.091$ & $0.75(<$ LOD $)$ \\
S14 & $<0.005$ & $0.74(<0.019)$ & $<0.091$ & $0.74(<$ LOD $)$ \\
S15 & $<0.005$ & $0.69(0.72)$ & $<0.091$ & $0.69(0.72)$ \\
\hline
\end{tabular}

petrochemical processes, and among a large list of PAHs, 16 of them are listed as "priority pollutants" by the Environmental Protection Agency of the USA, due to their widespread distribution in the environment, their mutagenicity, and carcinogenic and teratogenic properties (USEPA, 2014). In this study, 12 of PAHs were detected. In this study, a wide range of concentrations were detected for individual PAHs found in $\mathrm{CB}$, with an average value that was approximately 14-fold greater than that found in the GMSM. The greatest pollution levels in terms of total PAHs were observed in stations S7 and S10, as the first was related to the petrochemical industry, and the second was related to ship repair activities. According to Baumard et al. (1998b), the PAH levels present at this estuary are classified within the moderate pollution range (100-1000 $\mathrm{ng} / \mathrm{g})$. In addition, in $\mathrm{CB}$, the range of $\sum_{16}$ PAHs' concentration for both sampling campaigns (mean $186.9 \mathrm{ng} / \mathrm{g}$, range $5.46-881.63 \mathrm{ng} / \mathrm{g}$ dw) was similar to those found by de Almeida et al. (2018) (mean $105 \mathrm{ng} / \mathrm{g}$, range < LOD to $533 \mathrm{ng} / \mathrm{g}$ ) at Todos os Santos Bay (northeast Brazil), a site influenced by petroleum processing and other related activities. Moreover, a study conducted on sediments from Santa Marta, Colombia, showed that coal terminals are potential sources of PAHs. Comparisons between individual PAH concentrations for this study and those reported for Santa Marta showed that fluorene (12.51 vs. $2.4 \mathrm{ng} / \mathrm{g})$, phenanthrene (57.6 vs. $19.4 \mathrm{ng} / \mathrm{g})$, and fluoranthene (19.8 vs. $8.5 \mathrm{ng} / \mathrm{g}$ ) levels were all higher in $\mathrm{CB}$, with naphthalene (52.8 vs $19.62 \mathrm{ng} / \mathrm{g}$ ) being exception (Caballero-Gallardo et al., 2015).

The concentration ratios of specific pairs of PAHs have been widely used for the qualitative assessment of PAH sources (Darilmaz et al., 2019; Katsoyiannis et al., 2007; Liu et al., 2019). Sediments from CB were contaminated with PAH that are mainly derived from fuel combustion. However, specifically at S7, which was the sampling point closets to a petroleum refinery site, petrogenic-derived PAHs were found during both the dry and rainy seasons, conferring this place as a hot spot for these pollutants. The station S9, which was near a coal cargo port, also displayed these types of PAHs, but only during the rainy season. Petrogenic PAHs are emitted directly into the water and deposited in the sediments. In the case of pyrogenic PAHs, they are emitted into the air and then they reach the water and finally the sediments through atmospheric deposition. The PAHs found in sediments from the Grand Marsh of Santa Marta are entirely derived from fuel combustion and pyrogenic wood, as there are no industries at this site.

The National Oceanic and Atmospheric Administration (NOAA) has applied the TEL concept as a SQG for different PAHs. In this study, acenaphthylene 
Table 5 Concentration of UV filters and fragrances in sediment samples from CB and GMSM (ng/g, dw) during the rainy and dry seasons

\begin{tabular}{|c|c|c|c|c|c|c|}
\hline \multirow[t]{2}{*}{ Stations } & \multicolumn{2}{|l|}{ UV filters } & \multicolumn{4}{|l|}{ Fragrances } \\
\hline & 4MBC & Homosalate & Celestolide & OTNE & Tonalide & Galaxolide \\
\hline \multicolumn{7}{|l|}{$C B$} \\
\hline S1 & $<0.221$ & $<0.022(19.27)$ & $0.11(0.99)$ & $12.81(9.25)$ & $<0.122$ & $11.56(11.16)$ \\
\hline $\mathrm{S} 2$ & $<0.221$ & $<0.022(14.36)$ & $<0.041(0.45)$ & $45.37(4.87)$ & $2.25(0.49)$ & $19.06(10.84)$ \\
\hline S3 & $<0.221$ & $<0.022$ & $0.07(0.26)$ & $4.53(<0.034)$ & $<0.122$ & $3.32(0.29)$ \\
\hline S4 & $<0.221$ & $<0.022$ & $<0.041(0.72)$ & $5.16(0.11)$ & $<0.122$ & $5.04(2.68)$ \\
\hline S5 & $<0.221$ & $<0.022$ & $<0.041(0.61)$ & $<0.034$ & $<0.122$ & $1.59(2.55)$ \\
\hline S6 & $<0.221$ & $<0.022$ & $<0.041(0.37)$ & $4.72(<0.034)$ & $<0.122$ & $6.06(1.78)$ \\
\hline S7 & $52.83(17.97)$ & $<0.022$ & $3.75(6.95)$ & $5.97(25.13)$ & $<0.122$ & $2.85(22.15)$ \\
\hline S8 & $<0.221$ & $<0.022$ & $<0.041(0.13)$ & $8.90(3.34)$ & $<0.122$ & $1.56(1.20)$ \\
\hline S9 & $<0.221$ & $<0.022(15.88)$ & $<0.041(0.28)$ & $<0.034$ & $<0.122$ & $2.28(8.94)$ \\
\hline S10 & $3.55(<0.221)$ & $<0.022(16.04)$ & $0.41(0.45)$ & $<0.03(9.45)$ & $<0.122$ & $3.06(11.82)$ \\
\hline S11 & $1.11(0.68)$ & $<0.022$ & $0.33(0.35)$ & $1.06(<0.034)$ & $<0.122$ & $3.30(1.77)$ \\
\hline $\mathrm{S} 12$ & $0.32(<0.221)$ & $<0.022$ & $0.13(0.74)$ & $<0.034(0.58)$ & $<0.122$ & $3.13(2.14)$ \\
\hline Mean \pm SEM & $\begin{array}{l}4.89 \pm 4.37 \\
\quad(1.65 \pm 1.48)\end{array}$ & $--(5.47 \pm 2.35)$ & $\begin{array}{l}0.41 \pm 0.31 \\
\quad(1.00 \pm 0.55)\end{array}$ & $\begin{array}{l}7.38 \pm 3.65 \\
\quad(4.40 \pm 2.15)\end{array}$ & $\begin{array}{l}0.24 \pm 0.18 \\
\quad(0.10 \pm 0.04)\end{array}$ & $\begin{array}{l}5.23 \pm 1.48 \\
\quad(6.44 \pm 1.91)\end{array}$ \\
\hline Frequencies (\%) & $33.3(16.7)$ & $0(33.3)$ & $50(100)$ & $66.7(58.3)$ & $8.3(8.3)$ & $100(100)$ \\
\hline \multicolumn{7}{|l|}{$G M S M$} \\
\hline S13 & $<0.221$ & $<0.022$ & $<0.041(1.09)$ & $<0.034(2.10)$ & $<0.122$ & $0.40(4.64)$ \\
\hline S14 & $<0.221$ & $15.06(<0.022)$ & $<0.041(0.45)$ & $<0.034(8.05)$ & $<0.122$ & $0.10(6.59)$ \\
\hline S15 & $<0.221$ & $14.67(14.37)$ & $<0.041$ & $<0.034(5.88)$ & $<0.122$ & $<0.013(2.19)$ \\
\hline Mean \pm SEM & -- & $\begin{array}{l}9.91 \pm 3.47 \\
\quad(4.80 \pm 3.94)\end{array}$ & $-(0.52 \pm 0.32)$ & $-(5.34 \pm 1.94)$ & -- & $\begin{array}{l}0.17 \pm 1.06 \\
\quad(4.47 \pm 2.00)\end{array}$ \\
\hline Frequencies & - & $66.7(33.3)$ & $-(66.7)$ & $-(100)$ & - & $66.7(100)$ \\
\hline
\end{tabular}

UV filters and fragrance values in sediments corresponding to the dry season are shown in parentheses

Abbreviation: 4MBC 4-methylbenzylidene camphor, OTNE tetramethyl acetyloctahydronaphthalenes, Galax galaxolide

levels in S10 (RS and DS) were greater than TEL, a pattern also shared with phenanthrene, benzo[a] anthracene + chrysene, and fluoranthene concentrations in S10 (RS), S7 (RS), and S10 (RS), respectively. These results suggest that adverse biological effects may occur occasionally for these PAHs. However, with intensive refinery activities in $\mathrm{CB}$, PAHs may be generating some problems for ecosystem health. In fact, Caballero-Gallardo et al. (2015) found that sediments from port and coal transport sites of Santa Marta (Colombia) induced gene expression changes related to xenobiotics (CYPIAI) and oxidative esters $(N Q O 1)$ on HepG2 cells. In addition, $\mathrm{PAH}$ levels were lower (range $<$ LOD-89.9 ng/g) than those found in this study (range 4.46-881.63 ng/g), suggesting that these molecules are bioactive even at lower concentrations.
Polychlorinated biphenyls are chlorinated organic chemicals used in industrial and commercial products, such as electronic equipment, heat transfer fluids, waterproofing agents, and as plasticizers in paints and rubber sealants (ATSDR, 2000; Doble \& Kumar, 2005). PCBs do not easily degrade in the environment and thus bioaccumulate, which is why they are still found as contaminants at waste sites and in the environment. The most relevant information regarding $\mathrm{PCBs}$ in sediments was that they were only detected at the industrialized site, CB. The high PCB levels found at the S2, S7, S8, S10, S11, and S12 stations may have been related to their proximity to discharge from industries in this area. However, inputs from the Magdalena River through the Dique Channel cannot entirely be ruled out. The most frequently detected congeners were PCB101, PCB138, PCB153, 
Fig. 3 Viability of HepG2 cells exposed to $1 \%$ methanolic extracts of the sediments from Cartagena Bay and Grand Marsh of Santa Marta (GMSM). Data are expressed as mean \pm SEM. *Significant differences between seasons. The dotted line represents $50 \%$ survival

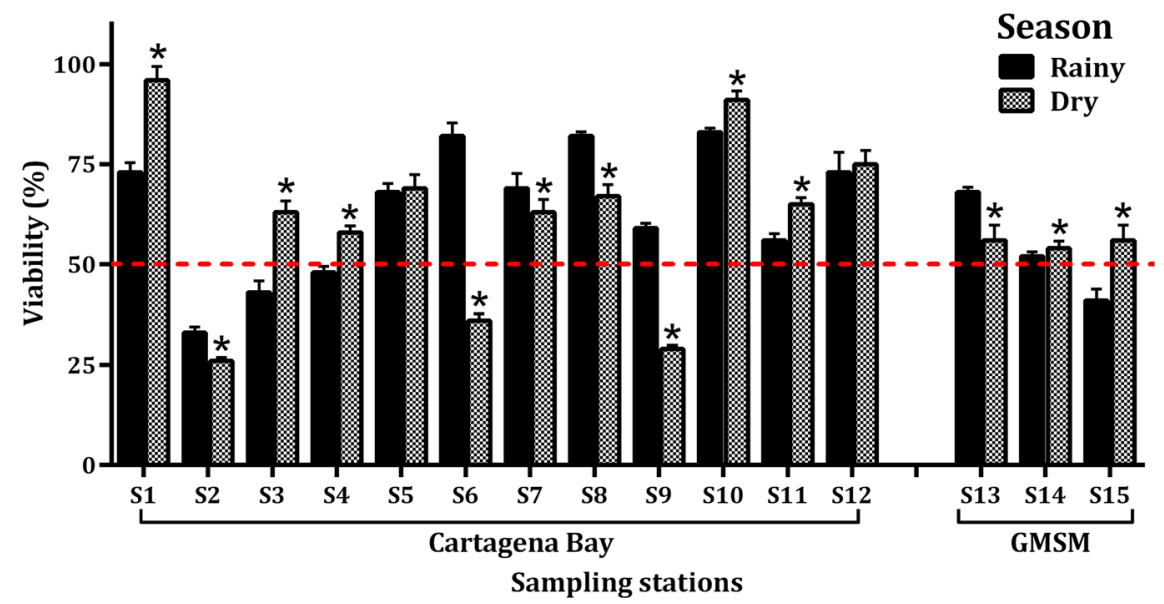

and PCB180. Interestingly, sediments from S11, a site near beverage industries showed measurable levels of all examined PCBs during both the rainy and dry seasons. In the case of PCB138, these results were comparable to those found in sediments from Masan Bay (Korea), a place that has experienced ecological disturbances related to aquaculture and eutrophication, as well as rapid industrialization (Hong et al., 2003). In general, the concentrations of total PCBs found in CB (from < LOD to $18.59 \mathrm{ng} / \mathrm{g}$ ) could be considered to be low compared to those reported by Wurl and Obbard (2005) in coastal marine sediments of Singapore (from 1.4 to $329.6 \mathrm{ng} / \mathrm{g}$ ), one of the world's largest industrial areas with some of the world's most intensive shipping traffic.

Organochlorine (DDT), organophosphate (chlorpyrifos), and pyrethroid (deltamethrin) pesticides have been identified in the marine environment (Domagalski \& Kuivila, 1993; He et al., 2019; Qu et al., 2018; Viganò et al., 2019). In Colombia, the use of these pesticides began to increase in the 1970s (Cárdenas et al., 2010), as they were used in cotton, corn, rice, and potato crops; with cotton being the crop in which they were in the greatest demand (Herrera, 1991). Among these pesticides, DDT was one of the most-used active ingredients; however, it was banned in Colombia in 1993 (Minambiente, 2007).

The degradation products of the pesticides DDT, such as DDD and DDE may occur through anaerobic processes, including reductive dechlorination to DDD and then dehydrochlorination of DDD to DDE. In the environment, dichlorodiphenyltrichloroethane degrades into its metabolites $p, p^{\prime}$-DDD and $p, p^{\prime}$-DDE under anaerobic and aerobic conditions, respectively (Heberer \& Dünnbier, 1999). In this study, the DDD/ DDE ratio was used to identify the type of degradation DDT had undergone (e.g., high DDD/DDE ratio indicates anaerobic conditions, and vice-versa) ( $\mathrm{Li}$ et al., 2017). In the present study, the data showed a high DDD/DDE ratio in the dry season (58\%), indicating the presence of anaerobic conditions ( $p, p^{\prime}$ DDD). In the case of the GMSM, it was not possible to calculate the DDD/DDE ratio because the levels were below the detection limit for $p, p^{\prime}$-DDE. In the marsh, the levels of $p, p^{\prime}$-DDD ranged between 0.09 and $0.10 \mathrm{ng} / \mathrm{g}$, which could be related to traces of DDT contamination due to its use in nearby crops.

According to Food and Agriculture Organization of the United Nations (FAO) statistics for the use of pesticides worldwide, Colombia ranked eighth with 73,744 tons of active ingredients used as pesticides in 2014. In addition, the Colombian Agricultural Institute (ICA) reported a production of $2,861,145 \mathrm{~kg}$ of chlorpyrifos and 147,246 L of deltamethrin for 2015 (ICA, 2015). In this case, the banana zone is one of the municipalities that makes up the GMSM, and in this zone, agrochemicals are used to keep the crop free of diseases. In this study, it was possible to quantify deltamethrin and chlorpyrifos at high concentrations, mainly in S15 (RS $14.57 \mathrm{ng} / \mathrm{g}$ and DS $17.18 \mathrm{ng} / \mathrm{g}$ ) and S14 (RS $6.50 \mathrm{ng} / \mathrm{g}$ and DS $48.90 \mathrm{ng} / \mathrm{g}$ ), providing evidence that these insecticides, likely used on banana crops and in the African palm industry, are impacting environmental health in the Ramsar Site, a problem that should be addressed by regional and national environmental agencies. 
OPFRs are another type of emerging pollutants present in several environmental compartments (Cristale et al., 2013). The highest tris (2-ethylhexyl) phosphate (TEHP) concentration was found in S7; this station is close to a petrochemical industry and a fertilizer plant. It has been reported that TEHP can be used as a flame retardant, and plasticizer (Wei et al., 2015), with the latter use a possible explanation for the high levels of TEHP in the sediments. Values found in sediments from the Bay were greater than those found in the Bohai and Yellow Seas, China (range 0.008-3.445 ng/g) (Zhong et al., 2018), as well as those reported in Spain, Cadiz Bay $(0.7 \mathrm{ng} / \mathrm{g})$ and the Huelva Estuary $(1.5 \mathrm{ng} / \mathrm{g}$ ) (Pintado-Herrera et al., 2017). In the case of the GMSM, ToTP was found in all three sampling sites, suggesting these chemicals are not only found at industrial sites.

UV filters and fragrances are widely used in various personal care products, and they have been reported in aquatic ecosystems in recent years (He et al., 2019). In this study, the highest $4 \mathrm{MBC}$ concentrations were observed in S7, S10, S11, and S12, which are areas that although do not receive direct inputs from tourist beaches, these may be serving as sinks for these chemicals transported across the bay.

High concentrations of fragrances were measured in stations where there are marine recreational areas (S1 and S2), also suggesting the deposition of these chemicals from personal-care products. Galaxolide, a chemical used in fragrances, is a polycyclic musk manufactured and used in a wide variety of commercial products such as perfumes, cosmetics, and lotions among others (Nakata et al., 2007). However, due to its widespread use and low rates of degradation, galaxolide has been detected throughout the environment, and several studies have reported its presence in sediments (Beretta et al., 2014; Jiang et al., 2018; Li et al., 2014).

The concentrations of galaxolide were in the range of 1.56-19.06 ng/g during the rainy season, and from 0.29 to $22.15 \mathrm{ng} / \mathrm{g}$ during the dry season. These were lower than the concentrations reported in the Jiaozhou Bay wetland in Qingdao, Shandong Province, eastern China (range 13.1-27.4 ng/g, mean $19.2 \mathrm{ng} / \mathrm{g}$ ) (Jiang et al., 2018), as well as those found in marine sediments from Brazil (mean $9.17 \mathrm{ng} / \mathrm{g}$ ) (Beretta et al., 2014). The frequency of detection for this xenobiotic in this site $(100 \%)$ was similar to that found in CB. However, Li et al. (2014) reported lower concentrations of this musk in sediments from Meiliang Bay, Taihu Lake (China) (range 0.27-0.79 ng/g), as also occurred in sediments collected in Yellow River, China (range 1.42-8.60 ng/g, mean $2.92 \mathrm{ng} / \mathrm{g}$ ) (Lou et al. (2016). In CB, the concentrations of fragrances tended to be higher at stations $\mathrm{S} 1$ and $\mathrm{S} 2$, which indicated that these are point sources of Galaxolide and OTNE pollution.

The cytotoxic activity in marine sediment extracts has been studied using different cell lines (CaballeroGallardo et al., 2015; Isla et al., 2018; Kocan et al., 1985). A reduction in cell viability (26-48\%) was observed in cells exposed to $1 \%$ extracts from stations S2, S3, S4, S15, S6, and S9. It has been suggested that the presence of PAHs in sediments may impair the viability of the HepG2 cells (Caballero-Gallardo et al., 2015; Pinto et al., 2014). However, at both CB and GMSM, maximum PAH levels did not match cytotoxicity, suggesting other stressors were involved. Interestingly, the Spearman correlation showed that among all contaminants present in the sediments, the levels of chlorpyrifos were most associated with the decrease in cell viability (Table S6 and Fig. S1), as was also shown by Zhou and $\mathrm{Li}$ (2018).

Principal component analysis (PCA) showed relationships between contaminants and their possible origin. A biplot summarizing PCA results is shown in Fig. 4 (Supplementary Tables S7 and S8) for pollutants found in CB and GMSM. The biplot regarding component loadings showed that the first component (PC1) was influenced by PCBs and PAHs. In addition, the distribution of the sampling stations based on their similarity is displayed in Fig. 4. The stations in the first and fourth quadrants (RS-S7, RS-S10, RS-S11, DS-S11, and RS-S12) showed high levels of pollutants, whereas stations in the second and third quadrants showed low concentrations (RS-S2, DS-S2, and DS-S12). The results suggest that stations S2, S7, S10, S11, and S12 are the main sources of PAHs and PCBs. These stations have industrial activities that have been reported as sources of these contaminants in marine sediments (Gevao et al., 2006; Wolska et al., 2012).

Based on its geographical and strategic position, Cartagena has a dynamic economic sector that includes petrochemical and plastic industry, ports, international trade, and tourism, as CB is an estuarine ecosystem that has been highly development, not only by the city but by Colombia. The number of national and international 
Fig. 4 Principal component (PC) biplot of the sampling sites and contaminants in marine sediments of $\mathrm{CB}$ and GMSM. The abbreviations of pollutants appear in the Tables 1-5, except for galaxolide (Galax), 2 ethylhexyl diphenyl phosphate $(\mathrm{EH})$, Deltamethrin(alfa + beta) (De), Chlorpyrifos (Ch), Homosalate $(\mathrm{H})$, and Celestolide (C)

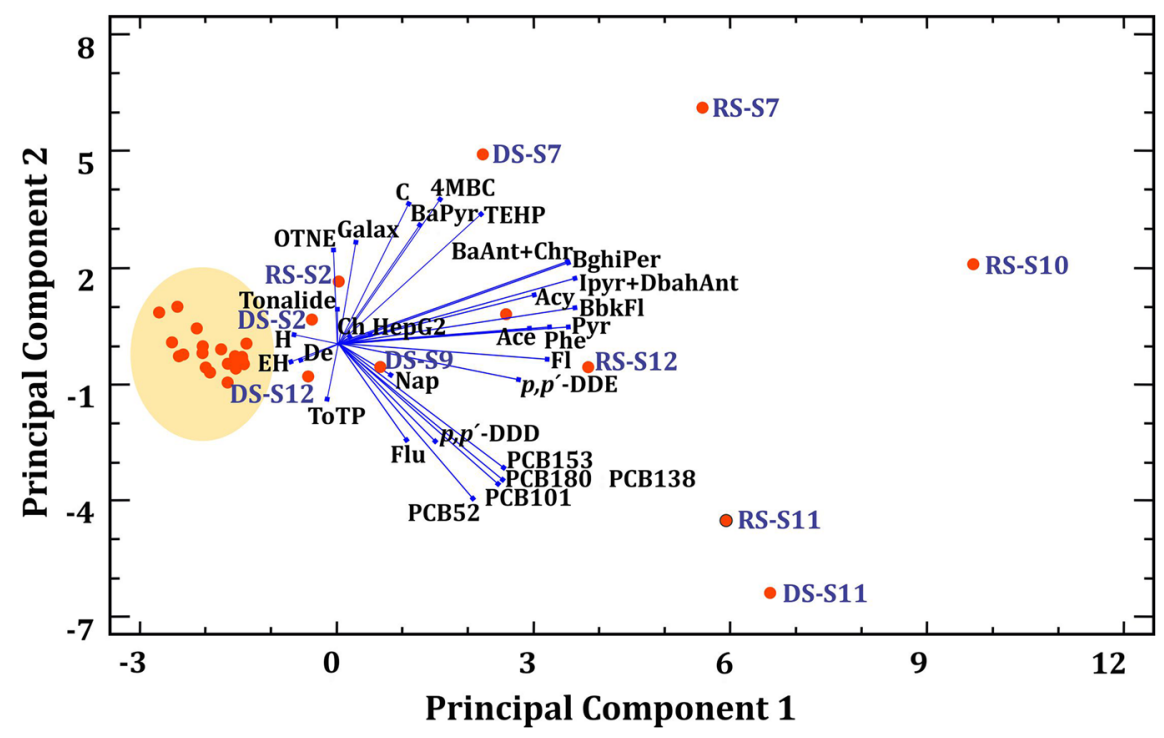

passengers during the year 2018 increased $9.1 \%$ and $41 \%$, respectively (CCCartagena, 2018). This situation demands infrastructure development and water supply for touristic and industrial purposes. However, at the same time, tourism has the potential to increase the use of UV filters and fragrances, making coastal regions susceptible to the effects of these pollutants. The impact caused by industry and tourism on this environment has been well documented (El Zrelli et al., 2018; Rahman et al., 2019), and this study clearly showed the footprint of both sectors due to the presence of PAHs, PCBs, pesticides, OPFRs, UV filters and fragrances in sediments. Therefore, this study should be used as an important tool for the implementation of public policies that facilitate the protection of ecosystems in order to ensure a healthier environment for citizens.

\section{Conclusions}

Industrialization and urbanization have environmental impacts on coastal marine ecosystems. This study reports a comprehensive evaluation of emergent contaminants and priority substances in surface sediments in Cartagena Bay and the Grand Marsh of Santa Marta, at the Colombian Caribbean. The following increasing trend of concentrations was found in Cartagena Bay: $\Sigma$ PAHs $>\Sigma$ Fragr ances $>\Sigma U V F>\Sigma$ PCBs $>\Sigma$ OPFRs $>$ pesticides, with maximum values registered at the stations related to industrial and urban activities. In contrast, deltamethrin was the only chemical with greater average levels detected in GMSM when compared to the Bay, probably as a result of its use in extensive crops along the eastern side of the Ramsar site. An interesting finding was to detect fragrances (Galaxolide) in the sediment samples from Cartagena Bay, indicating the impact of tourism in this ecosystem. Data from bioassays on HepG2 cells suggest some of the sediments are cytotoxic, and this bioactivity correlated with chlorpyrifos levels. These results should be employed to implement management programs needed to protect human and environmental health, as well as to support restoration plans for $\mathrm{CB}$ and GMSM.

Acknowledgements The authors thank the University of Cartagena (Resolution 02243 [2018] and Plan to Support Research Groups and Doctoral Programs [2019-2021]), and fishermen from Cartagena Bay and Grand Marsh of Santa Marta.

Author contribution All authors, Caballero-Gallardo, CoradaFernández, Lara-Martín, Juan-García, and Olivero-Verbel participated in all parts of the research for the development of this manuscript according to their expertise. All authors have read and agreed to the published version of the manuscript.

Funding Funding for this study was provided by ColcienciasUniversity of Cartagena (Grant FP448442-197/2017, Government of Bolivar, and General System of Royalties of Colombia, SGR). Sediment analysis was conducted at the University of Cadiz under Grant RTI2018-096211-B-I00. 
Data availability The data that support the findings of this study are available from the corresponding author.

\section{Declarations}

\section{Compliance with ethical standards Not applicable.}

Competing interests The authors declare no competing interests.

\section{References}

Akhbarizadeh, R., Moore, F., Keshavarzi, B., \& Moeinpour, A. (2016). Aliphatic and polycyclic aromatic hydrocarbons risk assessment in coastal water and sediments of Khark Island, SW Iran. Marine Pollution Bulletin, 108, 33-45.

Alonso, D., Pineda, P., Olivero, J., González, H., \& Campos, N. (2000). Mercury levels in muscle of two fish species and sediments from the Cartagena Bay and the Ciénaga Grande de Santa Marta, Colombia. Environmental Pollution, 109, 157-163.

ATSDR, (2000). Toxicological Profile for Polychlorinated Biphenyls (PCBs), pp. 765, Atlanta, Georgia, USA, US Department of Health and Human Services, Agency for Toxic Substances and Disease Registry (ATSDR) https:// www.atsdr.cdc.gov/ToxProfiles/tp17.pdf Accessed 16 June 2019.

Barco-Bonilla, N., Vidal, J. M., Frenich, A. G., \& RomeroGonzález, R. (2009). Comparison of ultrasonic and pressurized liquid extraction for the analysis of polycyclic aromatic compounds in soil samples by gas chromatography coupled to tandem mass spectrometry. Talanta, 78 , 156-164.

Baumard, P., Budzinski, H., \& Garrigues, P. (1998a). Polycyclic aromatic hydrocarbons in sediments and mussels of the western Mediterranean Sea. Environmental Toxicology and Chemistry, 17, 765-776.

Baumard, P., Budzinski, H., Mchin, Q., Garrigues, P., Burgeot, T., \& Bellocq, J. (1998b). Origin and bioavailability of PAHs in the Mediterranean Sea from mussel and sediment records. Estuarine, Coastal and Shelf Science, 47, 77-90.

Beretta, M., Britto, V., Tavares, T. M., da Silva, S. M. T., \& Pletsch, A. L. (2014). Occurrence of pharmaceutical and personal care products (PPCPs) in marine sediments in the Todos os Santos Bay and the north coast of Salvador, Bahia, Brazil. Journal of Soils and Sediments, 14, 1278-1286.

Caballero-Gallardo, K., Alcala-Orozco, M., Barraza-Quiroz, D., De la Rosa, J., \& Olivero-Verbel, J. (2020). Environmental risks associated with trace elements in sediments from Cartagena Bay, an industrialized site at the Caribbean. Chemosphere, 242, 125173.

Caballero-Gallardo, K., Guerrero-Castilla, A., JohnsonRestrepo, B., de la Rosa, J., \& Olivero-Verbel, J. (2015). Chemical and toxicological characterization of sediments along a Colombian shoreline impacted by coal export terminals. Chemosphere, 138, 837-846.

Cárdenas, O., Silva, E., \& Ortiz, J. E. (2010). Uso de plaguicidas inhibidores de acetilcolinesterasa en once entidades territoriales de salud en Colombia, 2002-2005. Biomédica, 30, 95-106.

Cardique. (2006). Bahía de Cartagena y Canal del Dique: Ecosistemas Estratégicos. https://guayacan.uninorte.edu. co/divisiones/Ingenierias/IDS/upload/File/Bahia_de_ Cartagena_ecosistema_nacional.pdf Accessed 04 March 2019.

CCCartagena. (2018). Cámara de Comercio Cartagena (CCCartagena). Informe de Gestión. http://www.cccartagena.org.

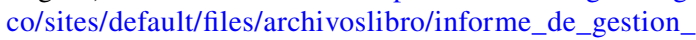
2018_ccc_0.pdf. Accessed July 302019.

CIOH. (2021a) https://www.cioh.org.co/meteorologia/Climatologia/ ResumenCartagena4.php (accessed June 05/2021)

CIOH. (2021b) https://www.cioh.org.co/derrotero/images/ PDFExternos/Climatologia_SantaMarta.pdf (accessed June 05/2021)

Cristale, J., Vázquez, A. G., Barata, C., \& Lacorte, S. (2013). Priority and emerging flame retardants in rivers: Occurrence in water and sediment, Daphnia magna toxicity and risk assessment. Environment International, 59, 232-243.

Darilmaz, E., Alyuruk, H., Kontas, A., Altay, O., Uluturhan, E., \& Bilgin, M. (2019). Distributions and sources of PAHs and OCPs in surficial sediments of Edremit Bay (Aegean Sea). Archives of Environmental Contamination and Toxicology, 77, 237-248.

de Almeida, M., \& do Nascimento, D.V., de Oliveira Mafalda Jr, P., Patire, V.F., \& de Albergaria-Barbosa, A.C.R. (2018). Distribution and sources of polycyclic aromatic hydrocarbons (PAHs) in surface sediments of a Tropical Bay influenced by anthropogenic activities (Todos os Santos Bay, BA, Brazil). Marine Pollution Bulletin, 137, 399-407.

Dehn, P. F., Allen-Mocherie, S., Karek, J., \& Thenappan, A. (2005). Organochlorine insecticides: Impacts on human HepG2 cytochrome P4501A, 2B activities and glutathione levels. Toxicology in Vitro, 19, 261-273.

Doble, M., \& Kumar, A. (2005). Chapter 6-Chlorinated hydrocarbons and aromatics, and dioxins. Biotreatment of Industrial Effluents. Pages 65-82. Elsevier.

Domagalski, J. L., \& Kuivila, K. M. (1993). Distributions of pesticides and organic contaminants between water and suspended sediment, San Francisco Bay, California. Estuaries, 16, 416-426.

Duarte-Restrepo, E., Noguera-Oviedo, K., Butryn, D., Wallace, J. S., Aga, D. S., \& Jaramillo-Colorado, B. E. (2021). Spatial distribution of pesticides, organochlorine compounds, PBDEs, and metals in surface marine sediments from Cartagena Bay, Colombia. Environmental Science and Pollution Research, 28, 14632-14653.

El Zrelli, R., Rabaoui, L., Alaya, M. B., Daghbouj, N., Castet, S., Besson, P., Michel, S., Bejaoui, N., \& Courjault-Radé, P. (2018). Seawater quality assessment and identification of pollution sources along the central coastal area of Gabes Gulf (SE Tunisia): Evidence of industrial impact and implications for marine environment protection. Marine Pollution Bulletin, 127, 445-452. 
Gevao, B., Beg, M. U., Al-Omair, A., Helaleh, M., \& Zafar, J. (2006). Spatial distribution of polychlorinated biphenyls in coastal marine sediments receiving industrial effluents in Kuwait. Archives of Environmental Contamination and Toxicology, 50, 166-174.

He, K., Hain, E., Timm, A., Tarnowski, M., \& Blaney, L. (2019). Occurrence of antibiotics, estrogenic hormones, and UV-filters in water, sediment, and oyster tissue from the Chesapeake Bay. Science of the Total Environment, 650, 3101-3109.

Heberer, T., \& Dünnbier, U. (1999). DDT metabolite bis (chlorophenyl) acetic acid: The neglected environmental contaminant. Environmental Science \& Technology, 33, 2346-2351.

Heredia, G. S., Saavedra, D. M. Q., Lopez, K., \& Tous, G. (2013). Evaluación de la calidad de agua en la Bahía de Cartagena durante la temporada seca de 2013. Boletin Cientifico CIOH, 31, 143-158.

Herrera, O. (1991). Agricultura biologica: Una alternativa frente al abuso de los agroquimicos. Dugandia 3.

Hong, S. H., Yim, U. H., Shim, W. J., Oh, J. R., \& Lee, I. S. (2003). Horizontal and vertical distribution of PCBs and chlorinated pesticides in sediments from Masan Bay, Korea. Marine Pollution Bulletin, 46, 244-253.

ICA. (2015). Instituco Colombiano Agropecuario (ICA). Estadísticas de comercialización de plaguicidas químicos de uso agrícola. https://www.ica.gov.co/areas/agricola/servicios/ regulacion-y-control-de-plaguicidas-quimicos/estadisticas/ boletinplaguicidas2015-12-12-2016.aspx

Isla, E., Pérez-Albaladejo, E., \& Porte, C. (2018). Toxic anthropogenic signature in Antarctic continental shelf and deep sea sediments. Science and Reports, 8, 9154.

Jaramillo-Colorado, B. E., Arroyo-Salgado, B., \& Ruiz-Garcés, L. C. (2015). Organochlorine pesticides and parasites in Mugil incilis collected in Cartagena Bay, Colombia. Environmental Science and Pollution Research, 22, 17475-17485.

Jiang, S., Wang, L., Zheng, M., Lou, Y., \& Shi, L. (2018). Determination and environmental risk assessment of synthetic musks in the water and sediments of the Jiaozhou Bay wetland, China. Environmental Science and Pollution Research, 25, 4915-4923.

Juan-García, A., Juan, C., Tolosa, J., \& Ruiz, M.-J. (2019a). Effects of deoxynivalenol, 3-acetyl-deoxynivalenol and 15-acetyl-deoxynivalenol on parameters associated with oxidative stress in HepG2 cells. Mycotoxin Research, 35, 197-205.

Juan-García, A., Tolosa, J., Juan, C., \& Ruiz, M.-J. (2019b). Cytotoxicity, genotoxicity and disturbance of cell cycle in HepG2 cells exposed to OTA and BEA: Single and combined actions. Toxins, 11, 341 .

Katsoyiannis, A., Terzi, E., \& Cai, Q.-Y. (2007). On the use of PAH molecular diagnostic ratios in sewage sludge for the understanding of the PAH sources. Is this use appropriate? Chemosphere, 69, 1337-1339.

Kocan, R., Sabo, K., \& Landolt, M. (1985). Cytotoxicity/genotoxicity: The application of cell culture techniques to the measurement of marine sediment pollution. Aquatic Toxicology, 6, 165-177.

Li, K., Zhu, X., Wang, Y., Zheng, S., \& Dong, G. (2017). Effect of aerobic exercise intervention on DDT degradation and oxidative stress in rats. Saudi J. Biol. Sci, 24, 664-671.
Li, M., Ye, J., Jing, Z., Xiangying, Z., Xiaolan, Z., \& Yingxin, Y. (2014). Distribution of synthetic musk in surface water and sediments from Meiliang Bay. Taihu Lake. Environ. Chem, 33, 630-635.

Liu, Y., Gao, P., Su, J., da Silva, E. B., de Oliveira, L. M., Townsend, T., Xiang, P., \& Ma, L. Q. (2019). PAHs in urban soils of two Florida cities: Background concentrations, distribution, and sources. Chemosphere, 214, 220-227.

López-Victoria, M., Rodríguez-Moreno, M., \& Zapata, F. A. (2015). A paradoxical reef from Varadero, Cartagena Bay, Colombia. Coral Reefs, 34, 231-231.

Lou, Y.-H., Wang, J., Wang, L., Shi, L., Yu, Y., \& Zhang, M.-Y. (2016). Determination of synthetic musks in sediments of Yellow River Delta wetland, China. Bulletin of Environmental Contamination and Toxicology, 97, 78-83.

Ma, J. K., Eldin, S., Fathy, W., El-Ghareeb, W. R., Elhelaly, A. E., Khedr, M. H., Li, X., \& Huang, X. C. (2019). Effects of pyrene on human liver HepG2 cells: Cytotoxicity, oxidative stress, and transcriptomic changes in xenobiotic metabolizing enzymes and inflammatory markers with protection trial using lycopene. BioMed Research International, 2019, 7604851.

Manuel Nicolaus, E. E., Law, R. J., Wright, S. R., \& Lyons, B. P. (2015). Spatial and temporal analysis of the risks posed by polycyclic aromatic hydrocarbon, polychlorinated biphenyl and metal contaminants in sediments in UK estuaries and coastal waters. Marine Pollution Bulletin, 95(1), 469-479.

McGrath, J. A., Joshua, N., Bess, A. S., \& Parkerton, T. F. (2019). Review of polycyclic aromatic hydrocarbons (PAHs) sediment quality guidelines for the protection of benthic life. Integrated Environmental Assessment and Management, 15, 505-518.

Medina-Díaz, I. M., \& Elizondo, G. (2005). Transcriptional induction of CYP3A4 by o, p'-DDT in HepG2 cells. Toxicology Letters, 157, 41-47.

Minambiente. (2007). Ministerio de Ambiente, Vivienda y Desarrollo Territorial. 2007. Consolidación del inventario de plaguicidas COP. http://quimicos.minambiente.gov. co/images/COP/plaguicidas/colombia__consolidacion_ inventario_plaguicidas_cop.pdf.

Mincomercio. (2021) https://www.mincit.gov.co/estudioseconomicos/estadisticas-e-informes/informes-de-turismo (accessed June 05/2021)

Morales-Caselles, C., Desforges, J. W., Dangerfield, N., \& Ross, P. S. (2017). A risk-based characterization of sediment contamination by legacy and emergent contaminants of concern in Coastal British Columbia, Canada. Archives of Environmental Contamination and Toxicology, 73(2), 270-284.

Mouyen, M., Longuevergne, L., Steer, P., Crave, A., Lemoine, J. M., Save, H., \& Robin, C. (2018). Assessing modern river sediment discharge to the ocean using satellite gravimetry. Nature Communications, 9(1), 3384.

Nakata, H., Sasaki, H., Takemura, A., Yoshioka, M., Tanabe, S., \& Kannan, K. (2007). Bioaccumulation, temporal trend, and geographical distribution of synthetic musks in the marine environment. Environmental Science \& Technology, 41, 2216-2222. 
Olivero-Verbel, J., Caballero-Gallardo, K., \& Torres-Fuentes, N. (2009). Assessment of mercury in muscle of fish from Cartagena Bay, a tropical estuary at the north of Colombia. International Journal of Environmental Health Research, 19, 343-355.

Olivero-Verbel, J., Caballero-Gallardo, K., \& Turizo-Tapia, A. (2015). Mercury in the gold mining district of San Martin de Loba, South of Bolivar (Colombia). Environmental Science and Pollution Research, 22, 5895-5907.

Parga-Lozano, C., Marrugo-González, A., \& Fernández-Maestre, R. (2002). Hydrocarbon contamination in Cartagena Bay, Colombia. Marine Pollution Bulletin, 44, 71-74.

Pico, Y., Belenguer, V., Corcellas, C., Díaz-Cruz, M. S., Eljarrat, E., Farré, M., Gago-Ferrero, P., Huerta, B., Navarro-Ortega, A., \& Petrovic, M. (2019). Contaminants of emerging concern in freshwater fish from four Spanish Rivers. Science of the Total Environment, 659, 1186-1198.

Pintado-Herrera, M. G., Combi, T., Corada-Fernández, C., González-Mazo, E., \& Lara-Martín, P. A. (2017). Occurrence and spatial distribution of legacy and emerging organic pollutants in marine sediments from the Atlantic coast (Andalusia, SW Spain). Science of the Total Environment, 605, 980-994.

Pintado-Herrera, M. G., González-Mazo, E., \& Lara-Martín, P. A. (2016). In-cell clean-up pressurized liquid extraction and gas chromatography-tandem mass spectrometry determination of hydrophobic persistent and emerging organic pollutants in coastal sediments. Journal of Chromatography A, 1429, 107-118.

Pinto, M., Costa, P. M., Louro, H., Costa, M. H., Lavinha, J., Caeiro, S., \& Silva, M. J. (2014). Human hepatoma cells exposed to estuarine sediment contaminant extracts permitted the differentiation between cytotoxic and pro-mutagenic fractions. Environmental Pollution, 185, 141-148.

Qu, C., Sun, Y., Albanese, S., Lima, A., Sun, W., Di Bonito, M., Qi, S., \& De Vivo, B. (2018). Organochlorine pesticides in sediments from Gulfs of Naples and Salerno, Southern Italy. Journal of Geochemical Exploration, 195, 87-96.

Rahman, M.S., Hossain, M.S., Ahmed, M.K., Akther, S., Jolly, Y.N., Akhter, S., Kabir, M.J., \& Choudhury, T.R. (2019). Assessment of heavy metals contamination in selected tropical marine fish species in Bangladesh and their impact on human health. Environmental Nanotechnology, Monitoring and Management, 11, 100210.

RAMSAR. (1998). Ramsar Sites Information Service. Sistema Delta Estuarino del Río Magdalena, Ciénaga Grande de Santa Marta. https://rsis.ramsar.org/ris/951 Accessed 04 January 2019.

Sicre, M. A., Marty, J. C., Saliot, A., Aparicio, X., Grimalt, J., \& Albaiges, J. (1987). Aliphatic and aromatic hydrocarbons in different sized aerosols over the mediterranean sea: Occurrence and origin. Atmosphere Environment, 21, 2247-2259.
Subedi, B., Yun, S., Jayaraman, S., Bergen, B. J., \& Kannan, K. (2014). Retrospective monitoring of persistent organic pollutants, including PCBs, PBDEs, and polycyclic musks in blue mussels (Mytilus edulis) and sediments from New Bedford Harbor, Massachusetts, USA: 1991-2005. Environmental Monitoring and Assessment, 186, 5273-5284.

Tarnawski, M., \& Baran, A. (2018). Use of chemical indicators and bioassays in bottom sediment ecological risk assessment. Archives of Environmental Contamination and Toxicology, 74(3), 395-407.

UNESCO. (2000). United Nations Educational, Scientific and Cultural Organization. Biosphere Reserve Information. http://www.unesco.org/mabdb/br/brdir/directory/biores. asp? code $=$ COL $+04 \&$ mode $=$ all Accessed 04 January 2019.

USEPA. (2014). United States Environmental Protection Agency. Priority Pollutant List. https://www.epa.gov/sites/ production/files/2015-09/documents/priority-pollutantlist-epa.pdf Accessed 04 January 2019.

Viganò, L., Stefani, F., Casatta, N., Mascolo, G., Murgolo, S., Roscioli, C., \& Zonta, R. (2019). Contamination levels and spatial distribution in the lagoons of the Po river delta: Are chemicals exerting toxic effects?. Estuarine, Coastal and Shelf Science, 231, 106467.

Wei, G.-L., Li, D.-Q., Zhuo, M.-N., Liao, Y.-S., Xie, Z.-Y., Guo, T.-L., Li, J.-J., Zhang, S.-Y., \& Liang, Z.-Q. (2015). Organophosphorus flame retardants and plasticizers: Sources, occurrence, toxicity and human exposure. Environmental Pollution, 196, 29-46.

Wei, W., Li, X. F., Li, X. N., Chen, X. M., Liu, A. L., \& Lu, W. Q. (2012). Oxidative stress and cell-cycle change induced by coexposed PCB126 and benzo (a) pyrene to human hepatoma (HepG2) cells. Enviro. Toxicol, 27, 316-320.

Wolska, L., Mechlińska, A., Rogowska, J., \& Namieśnik, J. (2012). Sources and fate of PAHs and PCBs in the marine environment. Critical Reviews in Environmental Science and Technology, 42, 1172-1189.

Wurl, O., \& Obbard, J. P. (2005). Organochlorine pesticides, polychlorinated biphenyls and polybrominated diphenyl ethers in Singapore's coastal marine sediments. Chemosphere, 58, 925-933.

Zhong, M., Wu, H., Mi, W., Li, F., Ji, C., Ebinghaus, R., Tang, J., \& Xie, Z. (2018). Occurrences and distribution characteristics of organophosphate ester flame retardants and plasticizers in the sediments of the Bohai and Yellow Seas, China. Science of the Total Environment, 615, 1305-1311.

Zhou, C., \& Li, X. (2018). Cytotoxicity of chlorpyrifos to human liver hepatocellular carcinoma cells: Effects on mitochondrial membrane potential and intracellular free $\mathrm{Ca}^{2+}$. Toxin Reviews, 37, 259-268.

Publisher's Note Springer Nature remains neutral with regard to jurisdictional claims in published maps and institutional affiliations. 